\title{
Diurnal and seasonal variations of soil respiration rate under different row-spacing in a Panicum virgatum L. field on semi-arid Loess Plateau of China
}

\author{
HUANG Jin ${ }^{1,2}$, GAO Zhijuan ${ }^{1}$, CHEN Ji ${ }^{1}$, ZHANG He ${ }^{1}$, XU Bingcheng ${ }^{1,2^{*}}$ \\ ${ }^{1}$ Institute of Soil and Water Conservation, Northwest A\&F University, Yangling 712100, China; \\ ${ }^{2}$ State Key Laboratory of Soil Erosion and Dryland Farming on the Loess Plateau, Institute of Soil and Water Conservation, \\ Chinese Academy of Sciences and Ministry of Water Resources, Yangling 712100, China
}

\begin{abstract}
Soil respiration (SR) in crop field is affected by environmental factors, agronomic practices and crop types. To clarify how planting density affects the SR dynamics in switchgrass (Panicum virgatum L.) field on the semi-arid Loess Plateau, this research investigated diurnal and seasonal changes of soil respiration rate $\left(R_{s}\right)$ under three different row-spacing treatments $(20,40$ and $60 \mathrm{~cm}$ ) in the fourth growing year of switchgrass. Results showed that Rs presented a pronounced seasonality under all row-spacing treatments. The highest daily average $\mathrm{R}_{\mathrm{S}}$ values appeared in August, while the lowest $(P<0.05)$ were in September for each row-spacing. Diurnal variations of $R_{S}$ exhibited single-peak curves in each month. Daily average $R_{s}$ increased significantly as row-spacing enlarged during May and August but there was no significant difference among row-spacing treatments in September. Soil water storage in the depth of $0-100 \mathrm{~cm}$ had no significant difference $(P>0.05)$ among the row-spacing treatments, and similar results were found for soil temperature in $0-15 \mathrm{~cm}$ soil depth. Soil respiration temperature sensitivity $\left(\mathrm{Q}_{10}\right)$ values were 1.0-3.7 during the growing months, which were strongly correlated with air temperature in May and June and the soil temperature at $15 \mathrm{~cm}$ depth in August. Higher aboveground biomass production and lower Rs in most growth months indicated that $20 \mathrm{~cm}$ row-spacing treatment was beneficial for increasing the carbon fixation in switchgrass field. Results also implied that it is necessary to take into account the influence of phenology and root growth of switchgrass on soil respiration for accurately evaluating the carbon cycle in the region.
\end{abstract}

Keywords: switchgrass; row-spacing; soil temperature; soil water; $\mathrm{Q}_{10}$ value

Citation: HUANG Jin, GAO Zhijuan, CHEN Ji, ZHANG He, XU Bingcheng. 2016. Diurnal and seasonal variations of soil respiration rate under different row-spacing in a Panicum virgatum L. field on semi-arid Loess Plateau of China. Journal of Arid Land, 8(3): 341-349. doi: 10.1007/s40333-016-0081-0

Soil respiration (SR) is the second largest $\mathrm{C}$ flux between the terrestrial system and the atmosphere, with a magnitude of 10 times greater than anthropogenic carbon dioxide production (Curiel-Yuste et al., 2004; Dornbush and Raich, 2006). Because it originates from autotrophic root respiration and heterotrophic microbial respiration in the rhizosphere and bulk soil, including the respiration from roots, the symbiont and microbial, SR is a comprehensive measurement of soil activity (Dornbush and Raich, 2006). Researches showed that SR can be affected by soil water (Jia et al.,

*Corresponding author: XU Bingcheng (E-mail: Bcxu@ms.iswc.ac.cn)
Received 2015-05-19; revised 2015-11-03; accepted 2015-11-10
(C) Xinjiang Institute of Ecology and Geography, Chinese Academy of Sciences, Science Press and Springer-Verlag Berlin Heidelberg 2016 
2004), soil temperature (Curiel-Yuste et al., 2004), soil aeration (Han et al., 2007) and root activity (Dornbush and Raich, 2006). Agronomy practices and cropping system, such as row-spacing, tillage method and fertilization, may affect soil physical and biological environments (i.e. soil water content, soil temperature and soil properties) and plant growth, which in turn impacts SR (Sun et al., 2009; Lü et al., 2011; Zhang et al., 2014). Soil respiration has been widely investigated in different vegetation and land uses, such as temperate desert (Huang et al., 2015), coastal wetland (Han et al., 2014), natural grassland (Peri et al., 2015) and crop land (Jiang et al., 2015). Agricultural farmland fields are important sources of atmospheric $\mathrm{CO}_{2}$ concentration and global C cycle (Zhang et al., 2014; Jiang et al., 2015), but limited information is available on SR characteristics in agro-ecosystems, especially in artificial grassland under different planting densities (i.e. row-spacing).

Switchgrass (Panicum virgatum L.) is a highly productive, perennial $\mathrm{C}_{4}$ warm-season bunchgrass, native to North America prairie (Lee et al., 2007). The high aboveground and underground biomass production make switchgrass a valuable bioenergy crop with the potential to increase soil C sequestration (Wright and Turhollow, 2010). In early 1990s, switchgrass was introduced and planted in semi-arid loess hilly-gully regions on the Loess Plateau and exhibited great eco-adaptability to different habitats in the area (Xu et al., 2005, 2008). However, plant or vegetation productivity should be moderately developed due to the limited water availability in the region, (Shan and Chen, 1993). It is also important to identify appropriate plants/crops with moderate biomass production and water consumption level in appropriate density (Shan and Chen, 1993; Xu et al., 2008). In recent decades, intensive researches about switchgrass focused on variety selection, method establishment, water and nitrogen use, biomass production and management, and environmental impacts (McLauglin and Kszos, 2005; Monti et al., 2007; Xu et al., 2008). Few studies measured soil respiration in switchgrass field, especially in water-limited regions (Wagle and Kakani, 2014). Thus, the objectives of this study were to: (1) clarify the seasonal variation characteristics of soil respiration, and its relationships with environmental factors; and (2) address the influence of soil temperature and moisture on soil respiration variations under different rowspacing treatments.

\section{Materials and methods}

\subsection{Site description}

A field experiment was conducted at Ansai Research Station (ARS) of Chinese Academy of Sciences (CAS) in Shaanxi province $\left(36^{\circ} 51^{\prime} 30^{\prime \prime} \mathrm{N}, 1^{\circ} 9^{\circ} 19^{\prime} 23^{\prime \prime} \mathrm{E}\right.$; $1,068 \mathrm{~m}$ asl). The annual mean temperature is $8.8^{\circ} \mathrm{C}$ in the region. The mean lowest temperature of the coldest month (January) is $-6.9^{\circ} \mathrm{C}$, while the mean highest temperature of the hottest month (July) is $22.6^{\circ} \mathrm{C}$. The annual active accumulated temperature $\left(\geq 10^{\circ} \mathrm{C}\right)$ is about $3,120^{\circ} \mathrm{C}$ and the frost-free period is 159 days. The mean annual precipitation is about $500 \mathrm{~mm}$, of which about $70 \%$ falls in July to September. The soil is wind-deposited loessial parent materials with a homogeneous silty clay loam texture classified as Calcic Cambosols. In the switchgrass field at different habitats, soil water content is about $6 \%$ in 0.6-2.0 m soil depth after the switchgrass growing about three years (Jiang et al., 2007).

\subsection{Experimental design}

Switchgrass seeds were sown on 15 July 2009 at $5 \mathrm{~g} / \mathrm{m}$ along a row, which was equivalent to 255 , 170 and $85 \mathrm{~kg} / \mathrm{hm}^{2}$ under 20, 40 and $60 \mathrm{~cm}$ row-spacing, respectively. The experiment used a randomized block design with three replications. The plot size was $12 \mathrm{~m}^{2}(3 \mathrm{~m} \times 4 \mathrm{~m})$ each. There was no irrigation or fertilization supplement since the experiment was established, and also during the experimental period.

\subsection{Soil water content measurement}

One aluminum tube $(4.0 \mathrm{~cm}$ in diameter, $4.0 \mathrm{~m}$ in length) was installed at the center of each plot to measure soil volumetric water content $\left(\theta_{v}\right)$. In this study, soil water content was only measured down to $100 \mathrm{~cm}$ soil depth at $10-\mathrm{cm}$ intervals and was measured monthly from April to October in 
2012 using intelligent water neutron meter (CNC-503DR, Beijing Hean Nucleus Co. Ltd., China). Soil water storage (SWS) in the $0-100 \mathrm{~cm}$ soil depth was calculated as:

$$
\mathrm{SWS}=\sum_{\mathrm{i}=1}^{20} \theta_{v} \times h_{i} \times 10 .
$$

Where $\theta_{v}$ is soil volumetric water content $\left(\mathrm{cm}^{3} / \mathrm{cm}^{3}\right)$ at a specific soil depth; $h_{i}$ is soil depth increment (i.e. $10 \mathrm{~cm}$ ); and the subscript $i$ stands for numbers of the soil depth intervals measured.

\subsection{Soil respiration rate and soil temperature measurement}

Soil respiration rate $\left(\mathrm{R}_{\mathrm{S}}\right)$ was obtained with an enclosed-chamber system for soil $\mathrm{CO}_{2}$ efflux measurement (PP-Systems, Amesbury, MA, USA). Living plants of switchgrass were removed with scissors one day before the measurement to avoid the effects of foliar respiration (Jia et al., 2014). One PVC-collar $\left(20 \mathrm{~cm}\right.$ in diameter, $16 \mathrm{~cm}$ in height) was installed in each plot thereafter. The $\mathrm{R}_{S}$ measurements were taken with a PP Systems (EGM-4) infrared gas analyzer (IRGA) that recorded $\mathrm{CO}_{2}$ concentration at 4-s intervals for $30 \mathrm{~s}$. Soil temperature (Ts) was measured at 5, 10 and $15 \mathrm{~cm}$ depths with digital thermometers. The measurements were carried out at 2-h intervals from 08:00 to 18:00 on the third sunny day in each month, and the experimental dates were 16 May, 12 June, 20 August and 13 September. Soil respiration and soil temperature were not measured in July due to the consecutive rainy days.

\subsection{Aboveground biomass and climatic factors}

The aboveground biomass was measured every year in October during 2009-2012. The swichgrass plant was cut by hand-held shears to ground level. The climatic factors, such as daily precipitation, air temperature and relative humidity in the year, were sourced from the meteorological station located close to the field (ca. $200 \mathrm{~m}$ ).

\subsection{Statistical analysis}

One-way ANOVA with the least significant differences (LSD) test was employed to compare the parameters (i.e. $R_{S}$, soil temperature and soil water content) across growing period or row-spacing treatments. Differences were considered significant at $P \leq 0.05$ level. To compare the relationship between soil $\mathrm{CO}_{2}$ flux and soil temperature, we used a first-order exponential function $\left(\mathrm{CO}_{2}\right.$ flux $=a \times \mathrm{e}^{b T}$ ) to simulate the relationship between soil respiration rate and temperature, where coefficient $a$ is the intercept of soil respiration, coefficient $b$ represents the temperature sensitivity of soil $\mathrm{CO}_{2}$ flux, and $T$ is the air or soil temperature (Lloyd and Taylor, 1994). Soil $\mathrm{CO}_{2}$ flux quotient $\left(\mathrm{Q}_{10}\right)$ was calculated using the formula $\mathrm{Q}_{10}=\mathrm{e}^{10 b}$ (Luo et al., 2001). All statistical tests were performed using SPSS 17.0 (SPSS, Chicago, USA).

\section{Results}

\subsection{Characteristics of environmental factors}

In 2012, total precipitation during the growing season (April to October) was $443 \mathrm{~mm}$, which was about $11.74 \%$ lower than the 1951-2000 average of $502 \mathrm{~mm}$. The precipitation during July to September was $303 \mathrm{~mm}$, close to the 50-year (1951-2000) average of $318 \mathrm{~mm}$. The precipitation in July, August and September was 118, 72 and $114 \mathrm{~mm}$, respectively (Fig. 1).

The diurnal variations of photosynthetically active radiation (PAR) showed a unimodal pattern, which ranged from 1,700 to $2,400 \mu \mathrm{mol} /\left(\mathrm{m}^{2} \cdot \mathrm{s}\right)$, with the maximum values occurred between 10:0014:00 in May to September (Fig. 2). Air temperature (Ta) was generally paralleled with PAR, increased from a low value at $8: 00\left(17^{\circ} \mathrm{C}-28^{\circ} \mathrm{C}\right)$ to a peak value $\left(25^{\circ} \mathrm{C}-35^{\circ} \mathrm{C}\right)$ between $12: 00$ and 14:00. The daily maximum and minimum mean air temperature were observed in June $\left(32.1^{\circ} \mathrm{C}\right)$ and September $\left(22.05^{\circ} \mathrm{C}\right)$, respectively (Fig. 2). The highest relative humidity $(\mathrm{RH})$ appeared at 8:00 in the morning and then decreased gradually during a day. The lowest daily mean $\mathrm{RH}$ was recorded on 12 June (Fig. 2). 


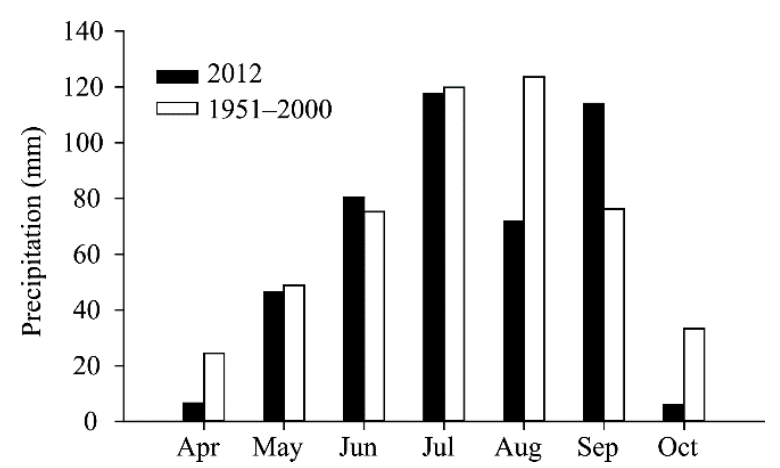

Fig. 1 Monthly precipitation distribution during the growing seasons in 2012 and 1951-2000
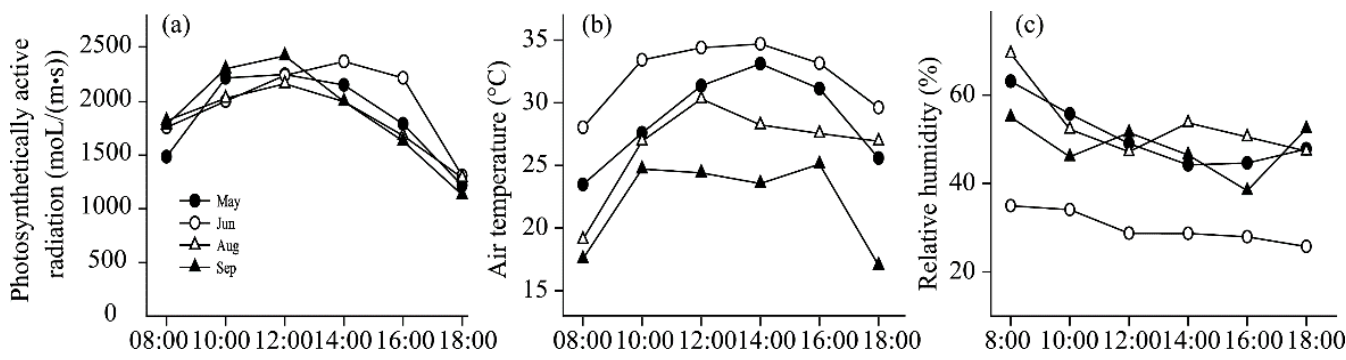

Fig. 2 Diurnal changes of photosynthetically active radiation (PAR), air temperature (Ta), and air relative humidity (RH) in the experimental months of 2012

\subsection{Aboveground biomass production}

From 2009 to 2012, the aboveground biomass production under each row-spacing increased significantly $(P<0.05)$ along with the age of the switchgrass. In 2009 and 2010, biomass production under the $20 \mathrm{~cm}$ row-spacing was significantly higher $(P<0.05)$ than those under the other two rowspacing treatments while there was no significant difference between these two treatments. In 2011 and 2012, biomass production decreased significantly as row-spacing increased. The biomass production was significantly higher under $20 \mathrm{~cm}$ row-spacing, while was significantly lower under $60 \mathrm{~cm}$ row-spacing (Fig. 3).



Fig. 3 Aboveground biomass production of switchgrass under each row-spacing treatment in 2009-2012. The letters on top of the bars indicated that there were significant differences among row-spacing treatments in each growth year at $P<0.05$ level.

\subsection{Soil water storage}

Soil water storage (SWS) at the 0-100 cm soil depth under different row-spacing treatments changed with time, which decreased gradually from April to June and then increased afterwards till September followed by a final decrease in October (Fig. 4). In April, SWS at the $0-100 \mathrm{~cm}$ soil 
depth were $120.5,129.8$ and $129.3 \mathrm{~mm}$ under 20,40 and $60 \mathrm{~cm}$ row-spacing, respectively. In June, it decreased sharply and reached the lowest values at 75.5, 78.2 and $84.1 \mathrm{~mm}$ under 20, 40 and 60 $\mathrm{cm}$ row-spacing, respectively. In October, SWS values were 115.0, 124.5 and $124.8 \mathrm{~mm}$ for 20, 40 and $60 \mathrm{~cm}$ row-spacing treatments which were about $4.6 \%, 4.1 \%$, and $3.5 \%$ lower than those in April. There were no significant difference among the three row-spacing treatments in SWS during the switchgrass growing months in 2012.

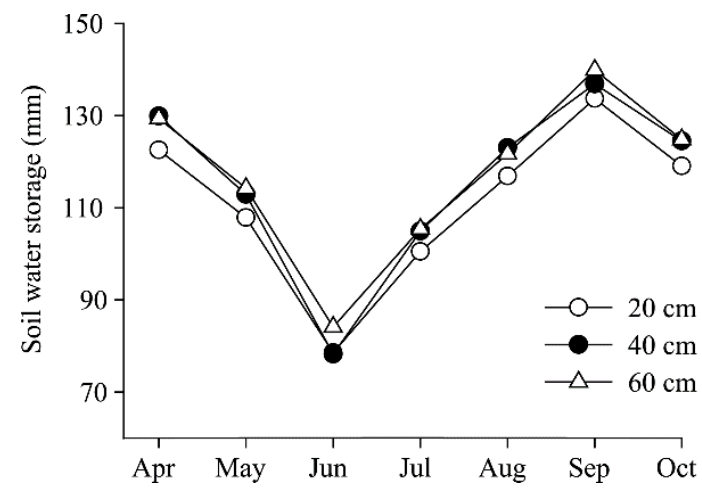

Fig. 4 Monthly mean soil water storage at $0-100 \mathrm{~cm}$ soil depth in the switchgrass field under different rowspacing treatments in 2012

\subsection{Soil temperature}

In each experimental day, soil temperature $\left(\mathrm{T}_{\mathrm{S}}\right)$ increased gradually from 8:00 in the morning and reached the highest point at 14:00 in May and June, or at 16:00 in August and September, and then declined gradually till 18:00 in the afternoon (Fig. 5). Except at $10 \mathrm{~cm}$ soil depth in May and June during 14:00-16:00, there were no significant differences in $\mathrm{T}_{\mathrm{S}}$ values among row-spacing treatments or soil depth in each month. The daytime lowest $T_{S}$ appeared at 8:00 in the daytime for each soil depth except for August, where $T_{S}$ values were similar at 8:00 and 18:00 in each soil depth. The daily variation of $\mathrm{T}_{\mathrm{S}}$ values (i.e. the maximum minus the minimum values in the daytime) decreased as soil depth increased (Fig. 5).

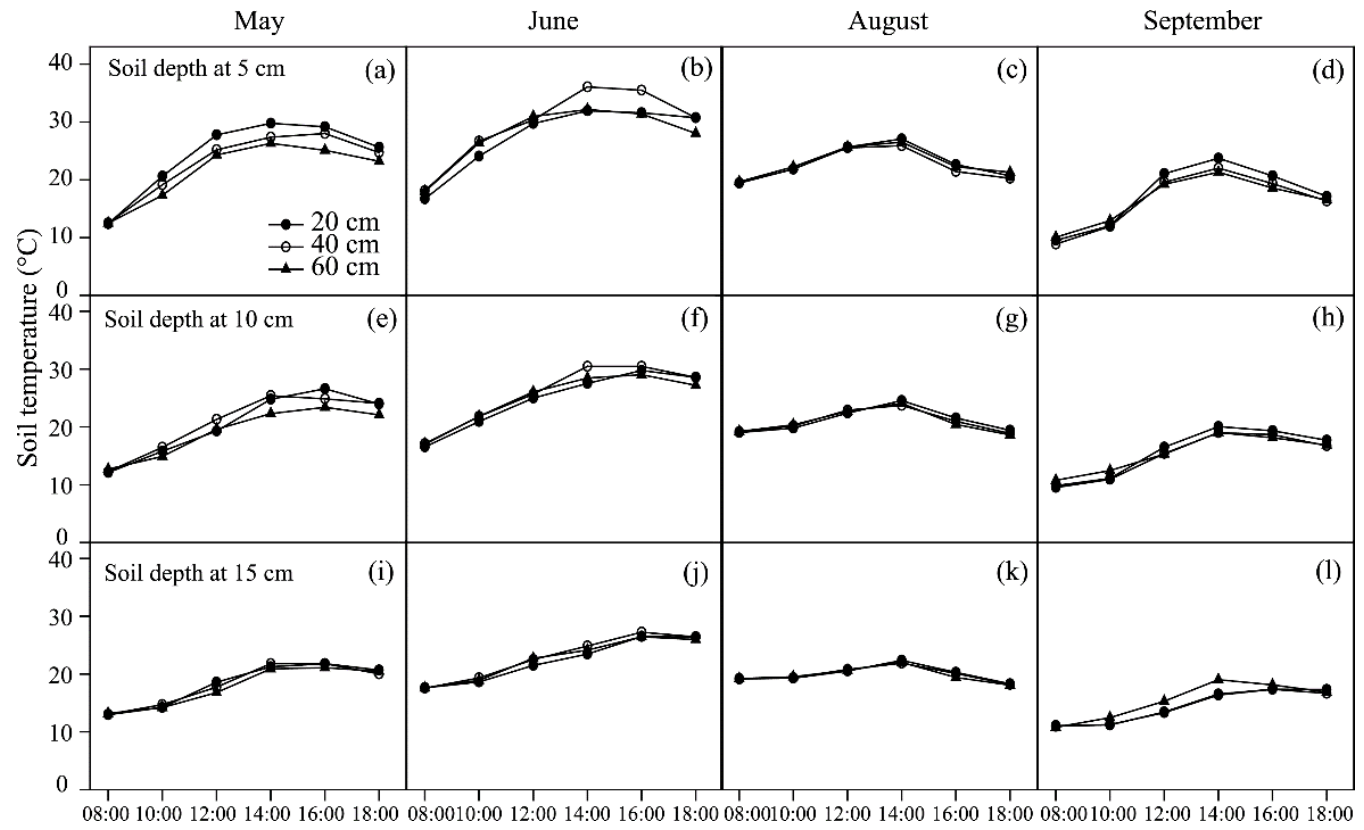

Fig. 5 Diurnal changes of soil temperature in the switchgrass field during the experimental months under rowspacing of 20,40 and $60 \mathrm{~cm}$ in 2012 


\subsection{Soil respiration}

Diurnal variations of $\mathrm{R}_{\mathrm{S}}$ exhibited single-peak curves under all treatments over the experimental period (Fig. 6). Daily averaged $\mathrm{R}_{\mathrm{S}}$ increased significantly with the increase of row-spacing in May $\left(0.80,1.13\right.$ and $\left.1.37 \mathrm{~g} \mathrm{CO}_{2} /\left(\mathrm{m}^{2} \cdot \mathrm{h}\right)\right)$, June $\left(0.85,1.10\right.$ and $\left.1.27 \mathrm{~g} \mathrm{CO}_{2} /\left(\mathrm{m}^{2} \cdot \mathrm{h}\right)\right)$ and August $(1.82,1.91$ and $\left.2.14 \mathrm{~g} \mathrm{CO}_{2} /\left(\mathrm{m}^{2} \cdot \mathrm{h}\right)\right)$ for 20,40 and $60 \mathrm{~cm}$ row-spacing, respectively; while in September, there were no significant difference among row-spacing treatments, and the values were $1.05,1.10$ and $1.06 \mathrm{~g} \mathrm{CO}_{2} /\left(\mathrm{m}^{2} \cdot \mathrm{h}\right)$ for 20,40 and $60 \mathrm{~cm}$, respectively. In August, $\mathrm{R}_{\mathrm{S}}$ was about $1.8-2.3 \mathrm{~g} \mathrm{CO}_{2} /\left(\mathrm{m}^{2} \cdot \mathrm{h}\right)$ in the morning at 8:00, while in the other three months, it began at about $0.3-1.0 \mathrm{~g} \mathrm{CO}_{2} /\left(\mathrm{m}^{2} \cdot \mathrm{h}\right)$. In May and June, the Rs values under all three row-spacing showed similar daily trends, with maximum value appeared at 14:00 in May or at 16:00 in June, respectively. In August, daily maximum values for 40 and $60 \mathrm{~cm}$ row-spacing appeared at 14:00, while it was at 16:00 for $20 \mathrm{~cm}$ rowspacing. The highest daily averaged $\mathrm{R}_{\mathrm{S}}$ appeared in August, and daily maximum $\mathrm{R}_{\mathrm{S}}$ values appeared at 12:00 on 13 September for each row-spacing (Fig. 6).

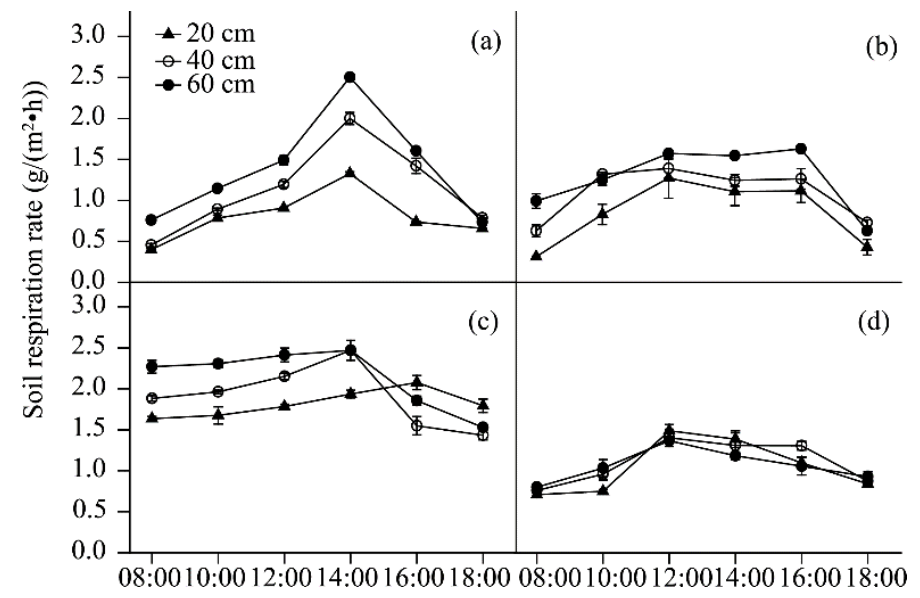

Fig. 6 Diurnal changes of soil respiration rate in switchgrass field under the row-spacing of 20, 40 and $60 \mathrm{~cm}$ on 19 May (a), 12 June (b), 20 August (c) and 13 September (d) in the experimental months of 2012

\subsection{Soil respiration temperature sensitivity}

Soil respiration temperature sensitivity $\left(\mathrm{Q}_{10}\right)$ values were 1.0-3.7 in switchgrass field during the growing months (Fig. 7). Q ${ }_{10}$ values calculated from air temperature were significantly higher

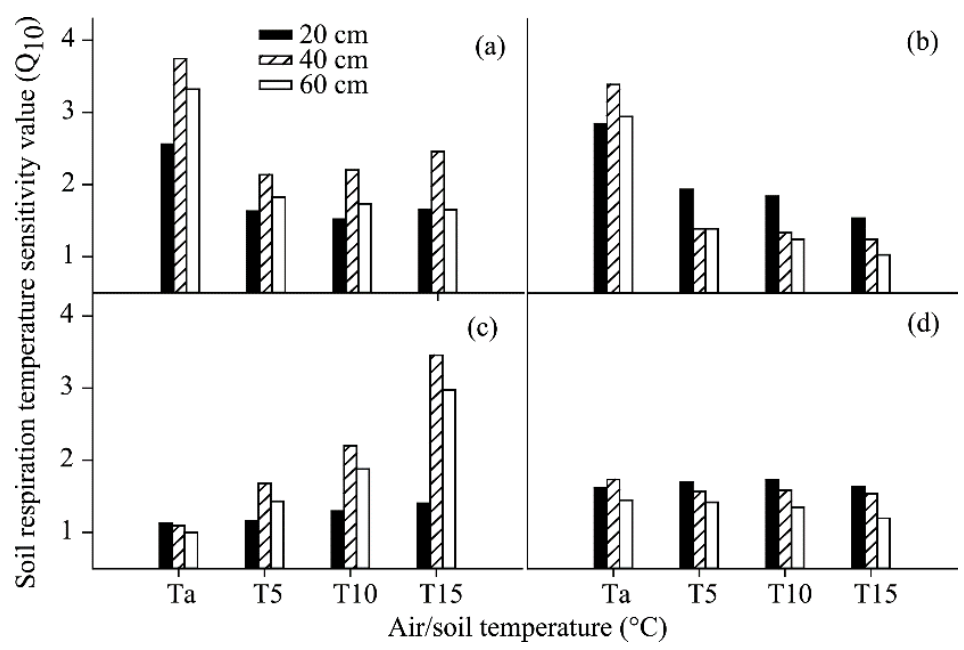

Fig.7 Q $Q_{10}$ values in switchgrass field under the row-spacing of 20, 40 and $60 \mathrm{~cm}$. Ta represents the air temperature. T5, T10 and T15 represent the soil temperatures at 5, 10 and $15 \mathrm{~cm}$ soil depths, respectively on 19 May (a), 12 June (b), 20 August (c) and 13 September (d) in the experimental months of 2012 
$(P<0.05)$ than those calculated from soil temperature in May and June, while there were no obvious trends in August and September. $Q_{10}$ values were much higher in May and June, than in August or September for each row-spacing treatment. In August, higher $\mathrm{Q}_{10}$ values were found to be more correlated with soil temperature at $15 \mathrm{~cm}$ soil depth, and decreased with soil depth. In September, there was no obvious changing trend in $\mathrm{Q}_{10}$ values with air temperature or soil temperature at 5, 10 or $15 \mathrm{~cm}$ soil depth (Fig. 7). In May and August, soil $\mathrm{Q}_{10}$ values calculated with soil temperature were much higher $(P<0.05)$ under $40 \mathrm{~cm}$ row-spacing, while in June and September those values were bigger $(P<0.05)$ under $20 \mathrm{~cm}$ row-spacing treatments (Fig. 7).

\section{Discussion}

The diurnal changes of $\mathrm{R}_{\mathrm{S}}$ exhibited single peak curves under all row-spacing treatments in each month with the highest value appeared at noon (Fig. 6), which were similar to the results obtained by other researches (Lü et al., 2011; Wang et al., 2015). Soil water content may affect SR because low water content would limit the contact between microorganism and available substrate and therefore microorganisms could be dormant and/or die under low soil water conditions (Conant et al., 2004). In this study, no significant difference was observed in soil water content at $0-10,10$ 20 and 20-30 cm soil depths among three row-spacing treatments, suggesting that soil water content was not the main factor inducing the differences of $R_{S}$ ( Figs. 4 and 7).

The temperature sensitivity of $\mathrm{R}_{\mathrm{S}}\left(\mathrm{Q}_{10}\right)$ is a critical parameter for quantitatively assessing carbon balance response of the terrestrial ecosystem to soil or air temperature (Wang et al. 2010). Our results clearly showed that $\mathrm{Q}_{10}$ values in switchgrass field varied with growth months and rowspacing treatments, and the values were different when calculated with air temperature or soil temperature in different soil depth (Figs. 5 and 7). Q 10 value was affected by not only air and soil temperature but also the changes in soil water content, root biomass, litter inputs, microbial populations and other seasonally fluctuating conditions and processes (Curiel Yuste et al., 2004). Switchgrass normally reached the yearly highest aboveground biomass production since the third or fourth year of growth, and had the seasonal highest biomass production in August at different habitats in loess hilly-gully regions (Xu et al., 2005; Jiang et al., 2007). Higher aboveground biomass production with higher coverage could weaken the "block and delay effect" of solar radiation and heat conduction into the soil surface, and thus affects soil temperature and $\mathrm{Q}_{10}$ values (Pang et al., 2013; Wang et al., 2015). Most empirical models used to calculate the $\mathrm{Q}_{10}$ values based on seasonal patterns of SR and temperature, and have a constant $\mathrm{Q}_{10}$, which may over- or underestimate SR when considered its values at small research areas (Xu and Qi, 2001; Janssens and Pilegaard, 2003). Such as in this study, great variations in $\mathrm{Q}_{10}$ values calculated from air temperature or soil temperature in different soil depths implied that to choose appropriate temperature index was important in explaining or predicting SR and that $\mathrm{Q}_{10}$ values derived from monthly patterns of $R_{S}$ should be used with caution when using its to evaluate annual variations or predicting future changes of SR (Qi et al., 2010). Although it was found that an exponential model can be used to show $\mathrm{R}_{\mathrm{S}}$ response to air temperature or soil temperature in surface depth (Fig. 7), there were no significant differences among row-spacing in soil temperature at $0-15 \mathrm{~cm}$ soil depth, thus it could be concluded that the diurnal variation of soil respiration was mainly dominated by air temperature or other factors (Dornbush and Raich, 2006). Diurnal variations of air temperature were closely related with solar radiation, which was generally paralleled with PAR during the growing season (Fig. 2).

The differences in SR may be due to plant eco-physiological process and root activity differences among row-spacing treatments (Zhang et al., 2013; Gao et al., 2015). Several studies suggested that $\mathrm{R}_{\mathrm{S}}$ is directly dependent on plant photosynthesis or growth (Yuste et al., 2004; Dornbush and Raich, 2006; Kuzyakov and Gavrichkova, 2010). As an agronomical practice in agricultural cropping systems, row-spacing affects plant canopy structure, light interception, radiation use efficiency, biomass production, and thus consequently the soil environment (Ma et al., 2001; Mattera et al., 2013). Our former research results showed that leaf net photosynthetic rate increased with the increase of row-spacing, which may partially explain the higher $\mathrm{R}_{\mathrm{S}}$ for $60 \mathrm{~cm}$ row-spacing (Fig. 6) 
(Gao et al., 2015). Switchgrass had flexible strategy in root growth and distribution with its annual root biomass production accumulated most before September (Xu et al., 2010). Results showed that switchgrass started turning green in April with the highest growth rate in May, the maximum aboveground biomass production in August, and started to senesce in September (Xu et al., 2005). Thus, the monthly differences among row-spacing treatments in soil respiration may be due to root growth of switchgrass, which was the most active in May and its activity significantly decreased in September.

\section{Conclusions}

Better understanding of the effects of different row-spacing on soil respiration is important for accurately evaluating carbon cycle of plants/crops in semi-arid regions. Our results showed that both soil respiration rate and $\mathrm{Q}_{10}$ values varied with row-spacing and growth month in switchgrass field. Data indicated that aboveground biomass production was significantly higher, and $\mathrm{R}_{\mathrm{S}}$ was lower in most months of growing season under $20 \mathrm{~cm}$ row-spacing treatment, which implied that $20 \mathrm{~cm}$ row-spacing treatment was more beneficial for increasing carbon fixation in switchgrass field. Because switchgrass is a perennial species, row-spacing treatments affect its growth and ecophysiological process. Thus, further research is required to investigate the phenology and root growth differences of switchgrass among the months over the growing season and row-spacing treatments, and their relations with soil respiration rate and $\mathrm{Q}_{10}$ values. The findings presented here will be useful to integrate the biogeochemical process into rational planting of this bioenergy crop in large scale on the Loess Plateau regions.

\section{Acknowledgements}

This work was financially supported by the Program for New Century Excellent Talents in University (NCET-110444) and the Fundamental Research Funds for the Central Universities (ZD2013020).

\section{References}

Conant R T, Dalla-Betta P, Klopatek C C, et al. 2004. Controls on soil respiration in semiarid soils. Soil Biology and Biochemistry, 36(6): 945-951.

Curiel Yuste J, Janssens I A, Carrara A, et al. 2004. Annual Q ${ }_{10}$ of soil respiration reflects plant phenological patterns as well as temperature sensitivity. Global Change Biology, 10(2): 161-169.

Dornbush M E, Raich J W. 2006. Soil temperature, not aboveground plant productivity, best predicts intra-annual variations of soil respiration in central Iowa grasslands. Ecosystems, 9(6): 909-920.

Gao Z J, Xu B C, Wang J, et al. 2015. Diurnal and seasonal variations in photosynthetic characteristics of switchgrass in semiarid region on the Loess Plateau of China. Photosynthetica, 53(4): 489-498.

Han G X, Zhou G S, Xu Z Z, et al. 2007. Biotic and abiotic factors controlling the spatial and temporal variation of soil respiration in an agricultural ecosystem. Soil Biology and Biochemistry, 39(2): 418-425.

Han G X, Luo Y Q, Li D J, et al. 2014. Ecosystem photosynthesis regulates soil respiration on a diurnal scale with a short-term time lag in a coastal wetland. Soil Biology and Biochemistry, 68: 85-94.

Huang G, Li Y, Su Y G. 2015. Effects of increasing precipitation on soil microbial community composition and soil respiration in a temperate desert, Northwestern China. Soil Biology and Biochemistry, 83: 52-56.

Janssens I A, Pilegaard K. 2003. Large seasonal changes in $Q_{10}$ of soil respiration in a beech forest. Global Change Biology, 9(6): 911-918.

Jia X X, Shao M A, Wei X R, et al. 2014. Response of soil $\mathrm{CO}_{2}$ efflux to water addition in temperate semiarid grassland in northern China: the importance of water availability and species composition. Biology and Fertility of Soils, 50(5): 839-850.

Jiang J, Li D Q, Huang J. 2007. Growth of Panicum virgatum and soil moisture characteristics. Bulletin of Soil and Water Conservation, 27(5): 75-78, 88. (in Chinese)

Jiang J S, Guo S L, Zhang Y J, et al. 2015. Changes in temperature sensitivity of soil respiration in the phases of a three-year crop rotation system. Soil and Tillage Research, 150: 139-146.

Kuzyakov Y, Gavrichkova O. 2010. Time lag between photosynthesis and carbon dioxide efflux from soil: a review of 
mechanisms and controls. Global Change Biology, 16(12): 3386-3406.

Lee D K, Doolittle J J, Owens V N. 2007. Soil carbon dioxide fluxes in established switchgrass land managed for biomass production. Soil Biology and Biochemistry, 39(1): 178-186.

Lloyd J, Taylor J A. 1994. On the temperature dependence of soil respiration. Functional Ecology, 8(3): 315-323.

Lü P Y, Chai Q, Li G. 2011. Effects of fertilizing nitrogen levels on soil respiration during growing season in maize field. Pratacultural Science, 28(11): 1919-1923. (in Chinese)

Luo Y, Wan S, Hul D, Wallance L L. 2001. Acclimatization of soil respiration to warming in a tall grass prairie. Nature, 413 : $622-625$.

Ma Z, Wood CW, Bransby D I. 2001. Impact of row spacing, nitrogen rate, and time on carbon partitioning of switchgrass. Biomass and Bioenergy, 20(6): 413-419.

Mattera J, Romero L A, Cuatrín A L, et al. 2013. Yield components, light interception and radiation use efficiency of lucerne (Medicago sativa L.) in response to row spacing. European Journal of Agronomy, 45: 87-95.

McLaughlin S B, Kszos L A. 2005. Development of switchgrass (Panicum virgatum) as a bioenergy feedstock in the United States. Biomass and Bioenergy, 28(6): 515-535.

Monti A, Fazio S, Lychnaras V, et al. 2007. A full economic analysis of switchgrass under different scenarios in Italy estimated by BEE model. Biomass and Bioenergy, 31(4): 177-185.

Pang X Y, Bao W K, Zhu B, et al. 2013. Responses of soil respiration and its temperature sensitivity to thinning in a pine plantation. Agricultural and Forest Meteorology, 171-172: 57-64.

Peri P L, Bahamonde H, Christiansen R. 2015. Soil respiration in Patagonian semiarid grasslands under contrasting environmental and use conditions. Journal of Arid Environments, 119: 1-8.

Qi Y C, Dong Y S, Liu L X, et al. 2010. Spatial-temporal variation in soil respiration and its controlling factors in three steppes of Stipa L. in Inner Mongolia, China. Science China Earth Sciences, 53(5): 683-693.

Shan L, Chen G L. 1993. Theory and Practice of Dryland Farming on the Loess Plateau. Beijing: Chinese Science Press. (in Chinese)

Sun X H, Zhang R Z, Cai L Q, et al. 2009. Effects of different tillage measures on upland soil respiration in Loess Plateau. Chinese Journal of Applied Ecology, 20(9): 2173-2180. (in Chinese)

Wagle P, Kakani V G. 2014. Seasonal variability in net ecosystem carbon dioxide exchange over a young switchgrass stand. GCB Bioenergy, 6(4): 339-350.

Wang X, Yan Y C, Zhao S, et al. 2015. Variation of soil respiration and its environmental factors in Hulunber meadow steppe. Acta Ecologica Sinica, 35(1): 1-4. (in Chinese)

Wang X H, Piao S L, Ciais P, et al. 2010. Are ecological gradients in seasonal $\mathrm{Q}_{10}$ of soil respiration explained by climate or by vegetation seasonality? Soil Biology and Biochemistry, 42(10): 1728-1734.

Wright L, Turhollow A. 2010. Switchgrass selection as a "model” bioenergy crop: a history of the process. Biomass and Bioenergy, 34(6): 851-868.

Xu B C, Shan L, Li F M. 2005. Aboveground biomass and water use efficiency of an introduced grass, Panicum virgatum, in the semiarid loess hilly-gully region. Acta Ecologia Sinica, 25(9): 2206-2213. (in Chinese)

Xu B C, Li F M, Shan L. 2008. Switchgrass and milkvetch intercropping under 2:1 row-replacement in semiarid region, northwest China: Aboveground biomass and water use efficiency. European Journal of Agronomy, 28(3): 485-492.

Xu B C, Li F M, Shan L. 2010. Seasonal root biomass and distribution of switchgrass and milk vetch intercropping under 2:1 row replacement in a semiarid region in northwest China. Communications in Soil Science and Plant Analysis, 41(16): 19591973.

Xu M, Qi Y. 2001. Soil-surface $\mathrm{CO}_{2}$ efflux and its spatial and temporal variations in a young ponderosa pine plantation in northern California. Global Change Biology, 7(6): 667-677.

Zhang Q, Lei H M, Yang D W. 2013. Seasonal variations in soil respiration, heterotrophic respiration and autotrophic respiration of a wheat and maize rotation cropland in the North China Plain. Agricultural and Forest Meteorology, 180: 34-43.

Zhang Q B, Yang L, Xu Z Z, et al. 2014. Effects of cotton field management practices on soil $\mathrm{CO}_{2}$ emission and $\mathrm{C}$ balance in an arid region of Northwest China. Journal of Arid Land, 6(4): 468-477. 